\title{
ECOPEDAGOGIA: NA CONFLUÊNCIA DA BACIA HIDROGRÁFICA COM A BACIA PEDAGÓGICA
}

\section{ECOPEDAGOGY: IN THE CONFLUENCE OF HYDROGRAPHIC AND PEDAGOGICAL BASINS}

\section{ECOPEDAGOGIA: EN LA CONFLUENCIA DE LA CUENCA HIDROGRÁFICA CON LA CUENCA PEDAGÓGICA}

\author{
CATALÃO, Vera Margarida Lessa ${ }^{1}$ \\ MORAES, Josefina Reis de ${ }^{2}$
}

\begin{abstract}
RESUMO: Este trabalho, em forma de ensaio, aborda a bacia hidrográfica como área de confluência, e propõe o conceito de bacia pedagógica como conceito inspirador de uma articulação transdisciplinar entre as dimensões ecológicas e culturais que envolvem o elemento água. As chaves da ecopedagogia associadas às metáforas da água entretecem uma trama simbólica com o uso cotidiano da água e apontam caminhos para uma práxis pedagógica capaz de estimular flexibilidade, reciprocidade e criatividade nas comunidades de aprendizagem.
\end{abstract}

Palavras-chave: água; educação; metáfora; bacia hidrográfica; ecopedagogia.

\begin{abstract}
In this essay, the hydrographic basin is approached as a confluence area, proposing the concept of pedagogical basin as an inspiring idea for a trans-disciplinary articulation between the ecological and cultural dimensions involving water. Ecopedagogical keys associated to water metaphors weave a symbolic mesh with the daily use of this substance, pointing out ways for a pedagogical praxis able of encouraging flexibility, reciprocity and creativity in the learning communities.
\end{abstract}

Key words: water, education, metaphor, hydrographic basin, ecopedagogy

\footnotetext{
${ }^{1}$ Prof ${ }^{a}$ Dra do Programa de Pós- Graduação em Educação da Universidade de Brasília, orientadora de pesquisas na Área de Educação e Ecologia Humana e coordenadora, juntamente com a Prof ${ }^{a}$ Dr $^{\mathrm{a}}$ Maria do Socorro Rodrigues Ibanez, do projeto de Pesquisa e Extensão 'Água como matriz ecopedagógica”. veramcatalao@gmail.com

${ }^{2}$ Mestre em Gestão Ambiental pela Universidade Católica de Brasília e fundadora do Colégio INEDITO onde foi desenvolvida uma experiência pedagógica tendo a água como elemento articulador do currículo. josefinamoraes@yahoo.com.br
} 
RESUMEN: Este trabajo, en forma de ensayo, aborda la cuenca hidrográfica como área de confluencia, y propone el concepto de cuenca pedagógica como concepto inspirador de una articulación transdisciplinaria entre las dimensiones ecológica y cultural que envuelven al elemento agua. Las llaves de la ecopedagogía asociadas a las metáforas del agua, entretejen una trama simbólica con el uso cotidiano de las aguas e indican caminos para una praxis pedagógica capaz de estimular flexibilidad, reciprocidad y creatividad en las comunidades de aprendizaje.

Palabras-clave: agua; educación; metáfora; cuenca hidrográfica; ecopedagogia.

\section{INTRODUÇÃO}

Pertencemos a uma única comunidade e habitamos uma casa comum: a Terra e cada ser humano, assim como o nosso planeta, é composto de aproximadamente $70 \%$ de água. Desta percepção emerge a proposta de construção de um currículo ecopedagógico inspirado nos movimentos da água e na rede de sustentação da vida configurada nas bacias hidrográficas. Nesse contexto, a água pode nos ajudar a encontrar um caminho que devolva aos homens a percepção de sua identidade terrena.

A água nos mostra sua capacidade de religar, diluir, aceitar outros elementos, conduzir, fluir por caminhos diferentes tendo como destino correr e circular. Que outra metáfora pode ser mais propícia a uma educação para a paz, a solidariedade, e capacidade de invenção? a abordagem transversal proposta por René Barbier (1997), propõe que por meio de um espírito analógico, de uma escuta sensível e de uma prática multirreferencial possamos fazer surgir uma educação integral do ser humano. Evocar a bacia hidrográfica de um rio como uma metáfora de uma educação que articula diferenças, conjuga complexidades, separa águas que devem seguir direções distintas e reúne as que convergem para um mesmo vale caminha nessa direção.

Que imagem mais oportuna para o anel recursivo proposto por Edgar Morin que a do ciclo da água? a abertura das águas para o encontro com outras águas produz a existência dos seres pelo movimento, receptividade e impermanência. "a abertura produz a existência; o anel recursivo produz o ser. todo anel pressupõe uma abertura; não se pode dissociar a produção do ser da produção da existência. a existência é a produção de um ser que se produz sem cessar.” (Morin, 1999, p. 211). 
A memória de uma grande placenta planetária simbolicamente inscrita em nosso inconsciente coletivo poderá nutrir um imaginário social de solidariedade em lugar das rivalidades entre os humanos que partilham uma mesma bacia hidrográfica. Os estudiosos das mudanças climáticas são unânimes em afirmar que o aquecimento global afetará de forma impactante a oferta de água doce de qualidade ainda neste século. Diante desse novo cenário, também um outro imaginário está em gestação e deverá oscilar entre o temor e a veneração das águas.

A educação tem sido permanentemente convocada pela sociedade para responder aos desafios da crise ambiental contemporânea, o que nos motiva a refletir sobre seu papel na construção de novos valores na relação humanidade e natureza. Como a educação poderá contribuir para re-inventar outras formas de relação entre a cultura dos homens e os ciclos físicos e biológicos da natureza que de forma incontornável e ambivalente encontram-se entrelaçados?

Bachelard afirma que "não é o conhecimento do real que nos faz amar o real, o sentimento é o valor fundamental e primordial" (1999 p.132) o que nos remete à biologia do amor proposta por Maturana (2002) para uma relação de afeto e pertencimento entre a comunidade dos homens e a comunidade dos seres que habitam o planeta Terra. Uma práxis ecopedagógica pode nos conduzir na construção de uma cidadania ambiental e de uma cultura da sustentabilidade, mediante um fazer pedagógico que conjugue aprendizagem com os sentidos da vida cotidiana.

\section{A MATERIALIDADE SIMBÓLICA DA ÁGUA}

Entre o macrocosmo e o microcosmo inscrevem-se as mitologias buscando reatar natureza e cultura, tal como um centro virtual, que se encontra em toda parte, e cuja função é a de exprimir uma experiência total do mundo que transborda os limites do pensamento racional. Sua linguagem é o símbolo e sua origem, a imaginação. A função simbólica, ainda que ancorada na realidade material, permite dar um sentido ao que não está imediatamente presente. Através dos mitos, reflete Mircea Eliade (1999), as comunidades contam sua «verdadeira história », recuperando pela repetição da narrativa o sentido dado desde a primeira ocorrência de um fato. $\mathrm{O}$ mito conta uma 
história sagrada; relata um evento acontecido em um tempo primordial, o tempo fabuloso das origens, assim, graças à façanha de seres sobrenaturais, uma realidade ganha existência. O mito é sempre uma narrativa da criação.

Entre o céu e a terra, entre o sólido e o etéreo, encontra-se a água, assim como entre a matéria e o espírito encontra-se o mito. Entre dois mundos situa-se a terra encantada dos mitos, diz Joseph Campbell (2005). Nessa confluência dos espaços interior e exterior são engendrados os símbolos, na cavidade uterina da morada da alma, como percebia Novalis. Os mitos revelam que as leis que regulam o espaço exterior estão inscritas dentro de nós. Os ciclos das estações também regulam nosso corpo, mesmo quando pretendemos desconhecê-los. Como percebia Teilhard de Chardin (?) em sua obra "O fenômeno humano", nossos olhos são como olhos da Terra e nossa consciência, um estágio de auto-reflexão da matéria. A água é o elemento de mediação entre o mundo da materialidade e universo simbólico que engendra o sentido das coisas que percebemos e interagimos.

Símbolo de pureza e fertilidade, de purificação e regeneração, de punição e de benção, expressão da ira e do amor dos deuses, a água nutre o imaginário de todos os povos. A sua história aparece envolta em uma aura de mistério, o mesmo que tece as narrativas da origem da vida. Sabe-se que a sua forma líquida possibilitou a vida, mas pouco sabemos sobre a excepcionalidade deste momento cósmico. Elemento por excelência do oculto, a água invoca uma imaginação material voltada para as profundezas do ser, como percebe Bachelard: « A imaginação material da água é um tipo particular de imaginação. Ao conhecê-la o leitor compreenderá que a água é um tipo de destino, não somente o destino quimérico das imagens fugidias, o destino de um sonho que não se completa, mas um destino essencial que se metamorfoseia sem cessar na substância do ser». (1999:6).

Para Catalão (2002:189)“Quando a água reflete o céu é o universo inteiro que se duplica, numa metáfora extraordinária da consciência humana. A natureza passa a ser o outro da cultura e, neste jogo dialógico do objetivo e do reflexivo, emerge a consciência consciente de si - base de todo processo de hominização." O mito de Narciso apresenta este momento único da natureza que se reflete no olhar humano. Bachelard (op.cit. p.26) fala de um narcisismo cósmico: «Com Narciso e por Narciso, é toda floresta que 
se mira, é todo céu que toma consciência da sua grandiosa imagem". Narciso é belo por que o mundo é belo. Por intermédio da água ele pode perceber a si e a natureza, sua face é a face do mundo. "A água desvela, mas ao mesmo tempo vela. Sua transparência mostra o reflexo das coisas, enquanto resguarda sua profundeza. Elemento chave para a emergência da consciência, ela é ao mesmo tempo a metáfora mais perfeita das funções inconscientes.” (Catalão, 2006, p.85).

\section{ECOPEDAGOGIA E BACIA HIDROGRÁFICA}

A partir da bacia hidrográfica, propomos construir uma bacia pedagógica inspirada nas chaves de um processo educativo ecopedagógico proposto por Gutierrez e Prado (1999). Procuramos estabelecer relações entre estas chaves e as metáforas da água, na intenção de contemplar os múltiplos significados da Água como matriz ecopedagógica. As chaves favorecem uma pedagogia da pergunta que trabalha valores democráticos e solidários capazes de garantir a sustentabilidade da vida.

- A primeira chave, "faz-se o caminho ao caminhar", sugere que uma metodologia a partir do cotidiano não pode vir por meio de receitas prontas, mas deve ser construída no fluxo da experiência vivencial. Neste sentido, o curso do rio se faz entre o diálogo do tempo circular com o tempo linear. Podemos perceber cada curva, cada remanso com uma exaltação à circularidade original da água e ver nas correntes que impulsionam o fluxo, um diálogo com o vale e outras águas afluentes que trazem a marca da linearidade das histórias que se sucedem no trajeto de um rio da nascente até a foz. Essas representações podem inspirar uma reflexão analógica entre o curso dos rios e nossas histórias de vida;

- Na segunda chave, "caminhar com sentido" sugere uma análise sobre a nossa sensibilidade quanto ao significado e a direção que damos ao percurso de nosso rio, ou seja, como anda a nossa capacidade para sentir e contemplar as águas do rio de nossa história? Envolve ainda um sentir reflexivo, cujos caminhos são construídos a partir do sentimento, da intuição, da emoção, da vivência e da experiência, pois a educação "é um processo de elaboração do sentido" (Gutierrez e Prado, op.cit). 
- Na terceira, "caminhar em atitude de aprendizagem" podemos trabalhá-la por meio da lição de uma bacia hidrográfica sempre pronta e receptiva para acolher novas águas, que sejam escuras ou claras, fortes ou fracas, barrentas ou transparentes. Em todas, o rio encontra uma possibilidade de descoberta de outros ritmos e de renovação da paisagem do vale. É também uma metáfora apropriada para trabalhar o respeito às diferenças, isto é, viver a alteridade. Caracteriza-se por processos pedagógicos abertos, dinâmicos, convergentes, antagônicos e criativos, nos quais os principais autores são os seus protagonistas - alunos e professores.

- A quarta chave, "caminhar em diálogo com o entorno" pressupõe que a mediação pedagógica seja centrada na experiência dos interlocutores por meio de conversas fluidas, transparentes, sensíveis. A água é, por excelência, a senhora da escuta, condição essencial para a biologia do amor de que fala Maturana (2002). Para Gutierrez, a interlocução envolve a capacidade de chegar ao outro, de abrir-se ao meio ambiente, de percorrer caminhos de compreensão e reciprocidade, de promover processos e criar redes de aprendizagens;

- A quinta, "o caminhar como processo educativo" faz-nos lembrar que a água não surge apenas como elemento e veículo para geração e manutenção de vida, mas como fluxo, adaptabilidade e paisagem para contemplação, encantamento e reflexão. A imagem da cachoeira, cuja beleza inigualável pode ser utilizada para gerar a energia que move e toca a locomotiva do desenvolvimento, apresenta-se também como motivo para uma abordagem crítica das formas de desenvolvimento. Que energia escolhemos para sustentar nosso desenvolvimento humano e tecnológico?

- A sexta, "caminhar re-criando o mundo" abre espaço para a água oferecer um banho de poesia nas suas diferentes formas como se apresenta - ora gota, ora filete, ora corrente, ora onda, ora maré, o que nos remete para a elaboração de inúmeras metáforas criadoras e criativas sobre o nosso estar e agir neste mundo. Para Gutierrez e Prado (2002:71) “a expressão criadora leva o educando a passar de receptor a criador de informações, rompendo a dicotomia de mero expectador a recriador, de receptor passivo a agente de um processo de mudança". Como parte desse processo de criação e recriação, Edgar Morin (1993) afirma que "viver poeticamente é viver para viver", pela 
exaltação consciente do veio poético podemos integrar na vida prosaica os sentimentos, as emoções, as expressões genuínas de gozo, alegria, satisfação, prazer;

- A sétima chave, "caminhar avaliando o processo" abre espaço meditativo para se possa avaliar nossa aprendizagem sobre o sentido das coisas. Esta chave nos fala do tempo do remanso para refletir o nosso ser-estar e nos remete à ecologia da ação conceituada por Morin (1999). Quando compreendemos a vegetação como mãe e filha das águas, entendemos que o ato de desmatar a nascente implica que ela ficará exposta e poderá secar, remetendo-nos à consciência de que toda e qualquer ação traz uma reação, que precisa ser avaliada no processo, integrando-a aos resultados alcançados. A água resguarda os seres das arestas, da aridez e do peso da gravidade (Catalão, 2006) e assim apresenta-se como metáfora do cuidado essencial de que fala Heidegger e do modo de ser cuidado proposto por Boff (1999).

\section{CONCLUSÃO}

O movimento transversal e espiralado que estrutura as bacias hidrográficas inspira uma bacia pedagógica transdisciplinar que religa o corpo humano ao corpo da terra. A água apresenta-se como elemento articulador dos conhecimentos sistematizados, conhecimentos que emergem da prática, conhecimento popular, percepção estética e expressões simbólicas. O simbolismo das águas faz ainda conexões entre natureza e cultura. A água aparece também como traço de união entre a ação local - o rio da minha aldeia - e a perspectiva global - os oceanos.

Trabalhar com as metáforas permite-nos ir além das dimensões de encantamento e beleza, suscitando análises dos problemas do cotidiano, principalmente aqueles que o Planeta enfrenta em relação à disponibilidade e esgotamento dos recursos hídricos, podendo conduzir a um olhar crítico e atitude responsável diante das situações que se apresentam. Nesse sentido, estabelecemos ligação entre a crise da água com a crise de consciência da humanidade: "para que as águas revelem o céu é preciso transparência e limpidez. Turvo o espelho, disforme o reflexo, confusa a consciência" (Catalão, 2003).

A nossa Gaia-Terra circundada de águas é um lugar extraordinário capaz de converter os espaços desertos em lugares com possibilidade de criar, compartilhar e 
transformar, ainda que o homem contemporâneo esteja perdendo cada vez mais a capacidade de perceber-se como ser pertencente à Terra, optando por uma lógica e uma ética instrumental que coisifica todos os seres e mercantiliza as relações humanas. A este respeito Heidegger (1967) diz:

O modo que calcula e objetiva o real configura o desenraizamento próprio do homem moderno, sugerindo a formação de seres que saibam habitar, morar no sentido pleno, ou seja, respeitar a terra com seus seres, acolher e preservar, deixando o outro ser o legítimo outro com reconhecimento do sagrado e assumindo a morte como parte da vida.

É possível que ao conjugar as possibilidades da água como matriz ecopedagógica às chaves da ecopedagogia, possamos preencher ausências pedagógicas na educação ambiental, a exemplo do vazio acolhedor da água que favorece os encontros. Para nós educadores ambientais, a riqueza das metáforas é um oceano de possibilidades capaz ressignificar a água para as atuais e as novas gerações: "As metáforas são como redemoinhos de água: buscam nas profundezas das correntes o sentido mais perene da vida e da morte e o conduz à superfície para que possamos contemplá-lo." (Catalão 2002). Acreditamos que pelo modo de ser cuidado entrelaçado ao modo de ser trabalho (Boff, 1999) realizado cotidianamente, possamos devolver ao planeta Terra a transparência, o fluxo e a limpidez da sua matriz perene de Vida.

\section{REFERÊNCIAS BIBLIOGRÁFICAS}

BARBIER, René. L’approche transversale en sciences humaines. Paris: Harmatthan, 1997.

BACHELARD, Gaston. A água e os sonhos: ensaio sobre a imaginação da matéria. São Paulo: Martins Fontes, 1999.

CAMPBELL, Joseph (1904-1987). Joseph Campbell - entrevistas com Bill Moyers. Gravação em video DVD, 2005.

BOFF, Leonardo. Saber cuidar: ética do humano - compaixão pela terra. Petrópolis:RJ, Editora Vozes, 1999.

CATALÃO, V. M.L. L'eau comme métaphore ecopédagogique: une rechercheaction auprès d'une école rurale au Brésil. (Thèse de Doctorat). Paris: Université de Paris VIII, janvier, 2002.

CATALÃO, V. L. A crise da água e a turvação do espírito. Artigo publicado no Correio Brasiliense, em 10/03/2003. 
CATALÃO, V,M.L. As qualidades sensíveis da água in Água como matriz ecopedagógica: um projeto a muitas mãos. CATALÃO, V,M.L e IBANEZ, M.S.R (Orgs). Brasília: Departamento de Ecologia da Universidade de Brasília, 2006.

CHARDIN, Teilhard de. O fenômeno humano. Porto: Livraria Tavares Martins, 1970. ELIADE, Mircea. O sagrado e o profano - a essência de religião. São Paulo: Martins Fontes, 1999.

GUTIERREZ, F e CRUZ, P. Ecopedagogia e Cidadania Planetária. São Paulo: Cortez: Instituto Paulo Freire, 2002.

HEIDEGGER, Martin. Sobre o humanismo. Trad. Emmanuel Carneiro Leão, Rio de Janeiro: Tempo Brasileiro, 1967.

MATURANA, H. VARELLA, F. A Árvore do conhecimento: as bases biológicas da compreensão humana. São Paulo: Palas Athena, 2001.

MATURANA, H. Ontologia da realidade. Belo Horizonte: Editora UFMG, 2002.

MORIN, E. O Método II: a vida da vida. Portugal: Publicações Europa-América Ltda, 1999. 